\title{
Recoverable Quantity of Waste Heat from Kiln and Preheater Systems and Economic Analysis (Case of Messebo Cement Factory)
}

\author{
Halefom Kidane ${ }^{1} \quad$ Birhane Fisha $^{2} \quad$ Haftom Asmelash $^{3}$ Dawit Tafesse ${ }^{1}$ \\ 1.Hawassa university Institute of Technology, Hawassa Ethiopia \\ 2. Ethiopian Metal Engineering Corporation \\ 3. Ethiopian Institute of Technology Mekelle, Mekelle Ethiopia
}

\begin{abstract}
This project entitled "Recoverable quantity of waste heat at Messebo cement factor y" has tried to quantify the amount of heat loss, the amount of energy and cost saved from the waste heat. Here both primary and secondary data collection methods were included to carry out the study. So, the projects present starts by identifying the main source of waste (which part of cement have high loss), following calculated heat lost from the identified places or machines and final calculating the possible money saved if the waste heat changed to use full form or if it recovered Successful recovery waste heat contributes to lower fuel cost, lower electricity consumption. Kiln surface zones, Preheater cyclone 4 and 5 are the main areas in which high waste was occur. From Kiln surface zones $(959.13 \mathrm{~kJ})$, Preheater cyclone 4 and $5(587.199 \mathrm{~kJ})$ amount of heat is lost. From this lost we can recover around $62 \mathrm{~kW}$ power is recovered, $44155 \mathrm{kwhr} / \mathrm{month}$ energy and $26492 \mathrm{birr} / \mathrm{month}$ could be saved. It recommended the energy management department should invite and support others participation and to study on the heat recovery from the loosing of energy and to study on the alternative energy sources of the company.
\end{abstract}

Keywords: Waste heat, waste heat recovery system, Preheater, Kiln, energy,

DOI: $10.7176 /$ JETP/9-9-03

Publication date: December $31^{\text {st }} 2019$

\section{INTRODUCTION}

There are more than 10 cements factories in Ethiopia.Mesebo cement factory is among the largest and former plants which provides cement for the African largest dam which is known as great Ethiopian renaissance dam which has the capacity to produce 6050 mega Watt. In the country majority of cement factories their main source of power is electricity from of utility grid and imported fossil fuels like coal. Thus, they consume a lot of powers to perform their daily activity. As stated in [1 and 2] cement factories are among sector's which consumes high energy especially the clinker calcination process.

Due to the increase of human population and their demand of electricity increases parallelly. So, peoples are search an alternative option to meet their energy demand. Thus, they do either by introducing renewable source of energy, by hybridization different energy mixes or by optimization and increasing the efficiency of energy materials and equipment's. Besides these methods peoples are also started recovering the waste heat to generate power for different purposes. A model example of countries which are successfully produced power from waste of cement plants as indicated in [1] are India, China and South-east Asian countries.

As written in [3] the first heat recovery system was established in Japan in 1980 by Kawasaki Heavy Industry KHI at Sumitomo Osaka Cement. Then after, a key project with 15 MW capacity has been released in Kumagaya plant (Taiheiyo Cement). After almost two decades later as stated in [4] China was plant installed its first system in 1998 in partnership with a Japanese manufacturer. So, after many obstacles and modification we have reached in technology of waste heat recovery system to generate power from the flue gases. As described [5] some new generation of heat recovery installations in cement kilns producing up to $45 \mathrm{kWh}$ per ton of clinker currently worldwide.

Messebo cement factory utilize a large quantity of fuel and electricity that ultimately produce heat for a process and generates large amounts of exhaust heat during these manufacturing processes, as much as of the energy consumed is ultimately lost via waste heat, that simply passes out through the gas tubes (chimneys) into the atmosphere or into the surrounding without any recovery.

\section{1 waste heat}

A lot of authors and researches define in different ways .for examples as defined in [3] Waste heat is heat generated in a process by way of fuel combustion or chemical reaction and then goes into the environment without using it .Reference [4] also define waste heat as the extra heat that escapes from the system .Reference such as [7] also says Waste heat is the energy associated with waste streams of air, exhaust gases, and/or liquids that leave the boundaries of an industrial facility and enter the environment.

The amount of waste heat (Q) can be calculated by using equation (1) [6] 
$\mathrm{Q}=\mathrm{C} . \mathrm{m} . \Delta \mathrm{T}$.

Where $m=$ the mass of the heat carrying medium,

$\mathrm{C}=$ the heat capacity of the medium and

$\Delta \mathrm{T}=$ the temperature difference between the waste heat and ambient temperature

\subsection{Heat recovery}

As defined in [3] Heat recovery is a method of reducing the overall energy consumption of your site and therefore reducing the running costs. [ 8] Waste heat to power (WHP) is the process of capturing heat discarded by an existing industrial process and using that heat to generate power (see Figure 1) [8]

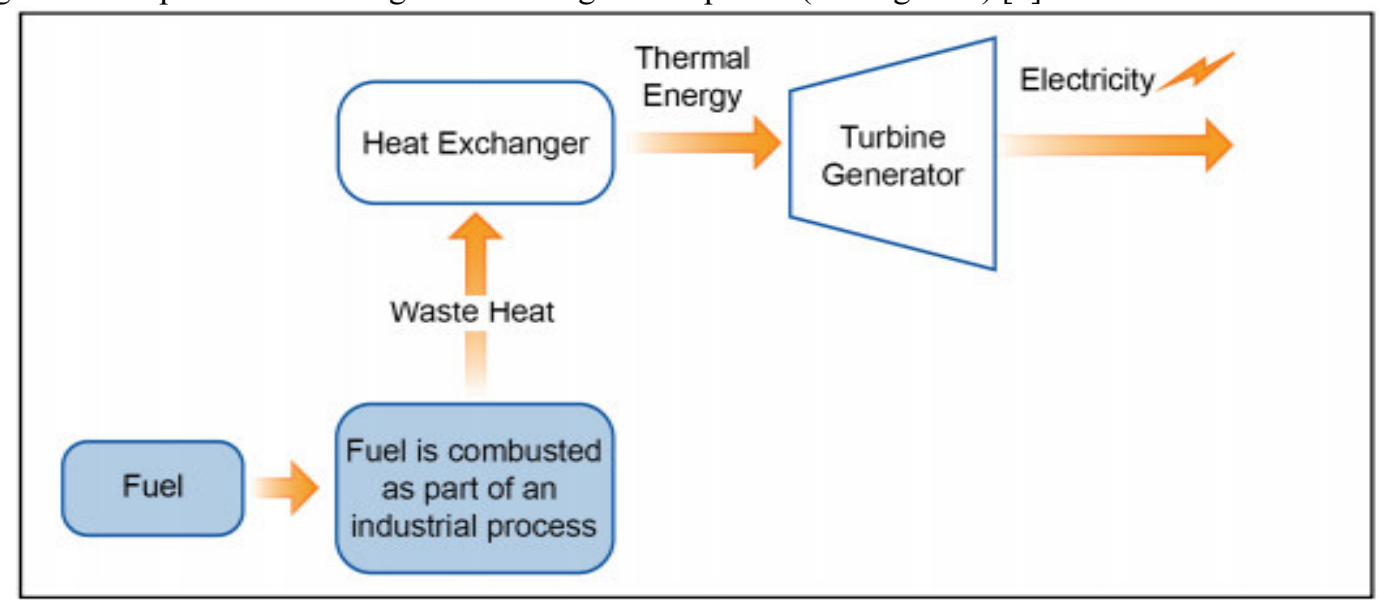

Figure 1: Waste Heat to Power Diagram [8]

Waste heat recovery has the following advantages [3 and 9]

- Reduces purchased power consumption (or reduces reliance on captive power plants), which in turn reduces operating costs.

- Mitigates the impact of future electric price increases

- Enhances plant power reliability

- Improves plant competitive position in the market

- Lowers plant specific energy consumption, reducing greenhouse gas emissions (based on credit for reduced

\section{METHODOLOGY}

\subsection{Description of the study area}

Messebo Cement Factory Private Limited Company (MCF PLC) is one of EFFORT (Endowment Fund for the Rehabilitation of Tigray) group companies established in accordance with the commercial code of Ethiopia. The company is located in Mekelle town in the Regional State of Tigray, $780 \mathrm{~km}$ from Addis Ababa, capital city of Ethiopia. The plant is located $7 \mathrm{~km}$ to the north-west of Mekelle town near Messebo hills. The machineries of the plant are designed and supplied by world renowned cement technology supplier FLSmidth of Denmark. The construction of the Messebo Cement Factory started in February 1997 G.C and was completed at the end of 1999. 


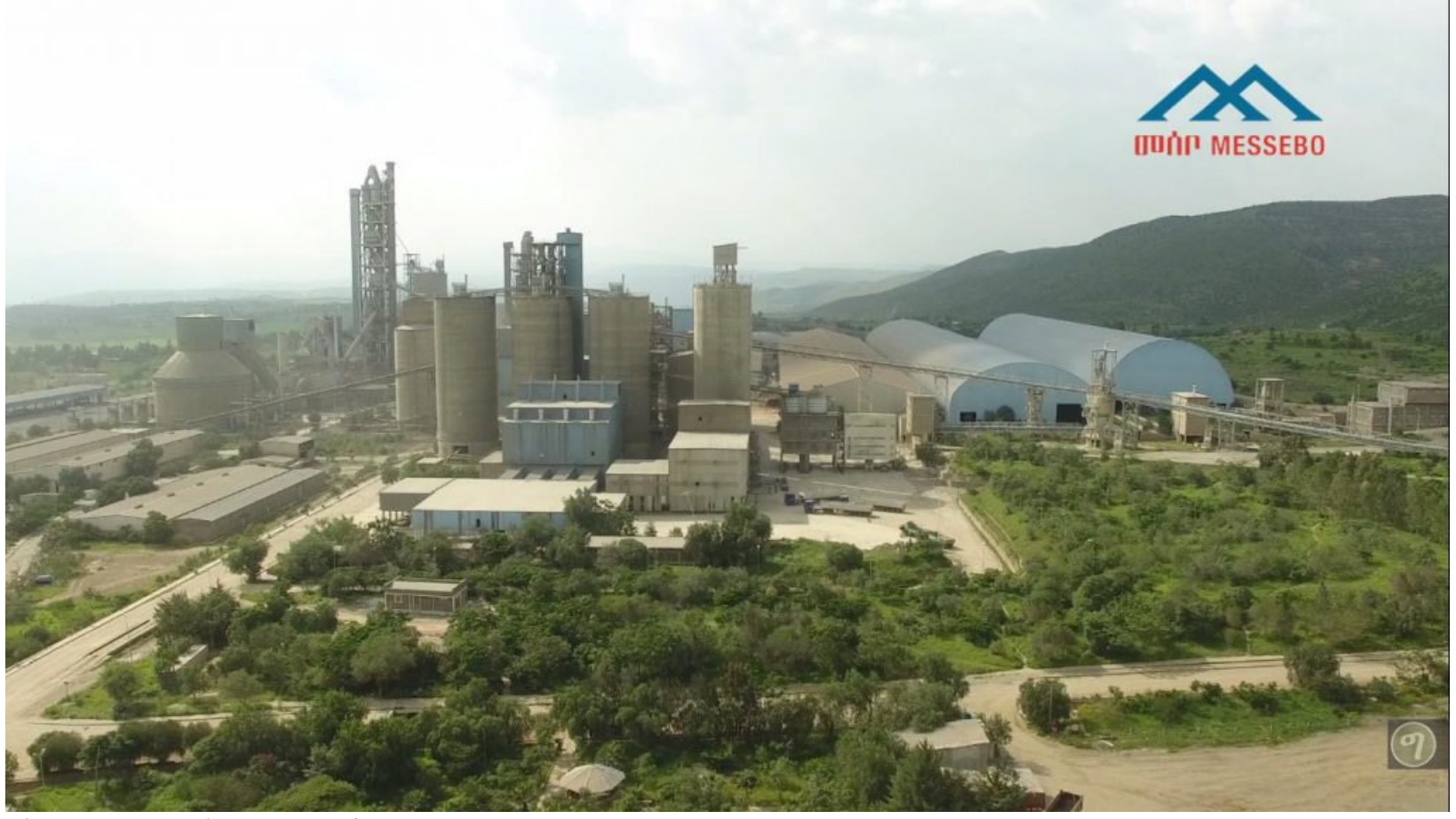

Figure 2: Messebo Cement factory

\subsection{Data collection}

In order to conduct this study, methods and procedures have great contribution for reaching the final result and of the paper. The methods used are discussed below in detail.

\subsubsection{Primary Data}

\section{Direct measurement and observation}

For this particular work the data were collected through measurements, formal and informal interview of company experts, machine manuals and direct observation. The temperatures of hot gases and air that loss to the atmosphere, heat loss by radiation were measured using the infrared thermometer,and direct observation from control class room $(\mathrm{CCR})$.

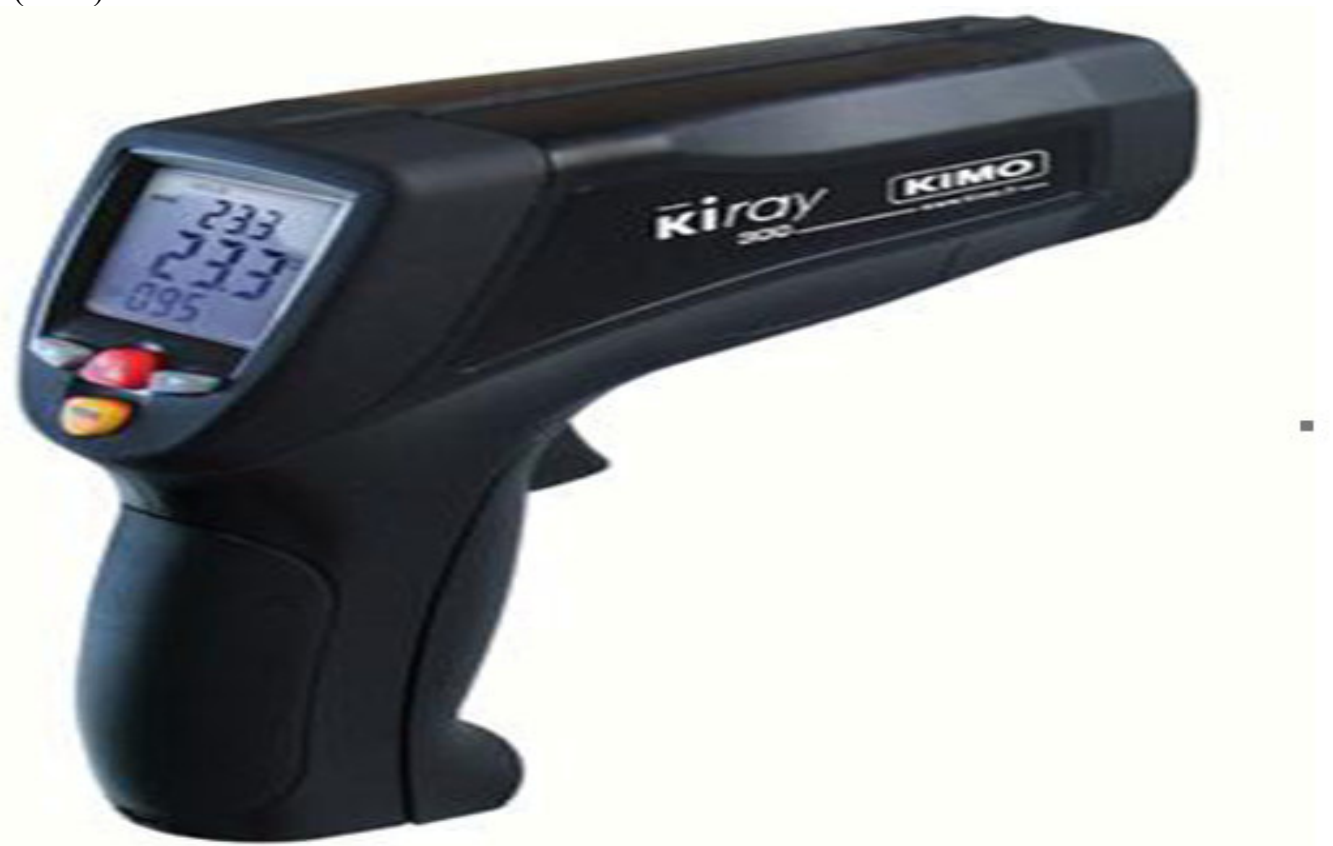

Figure 3: infrared thermo meter 


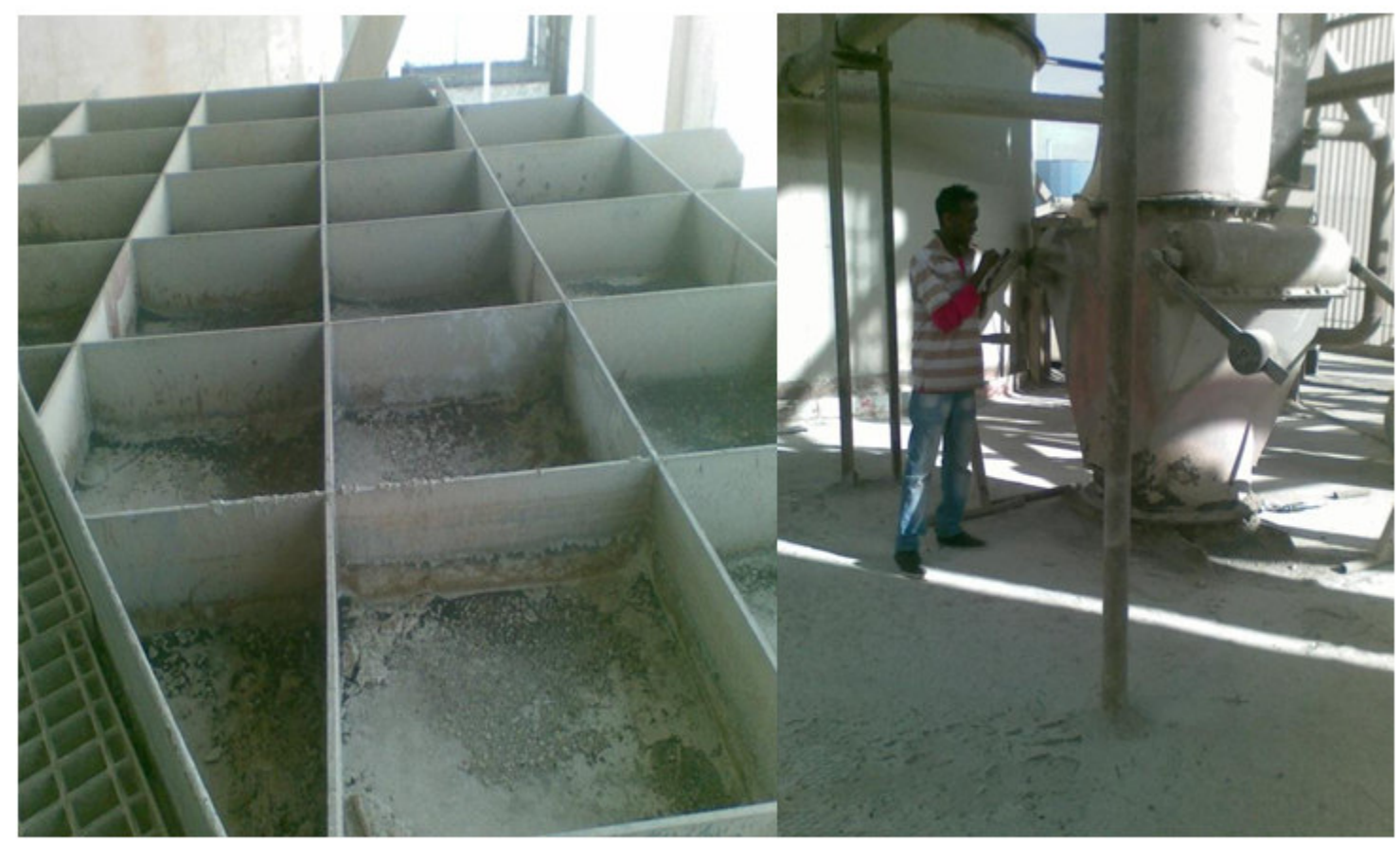

A

Figure 4: (A) top view of cyclone 4 (B) cyclone 5

\section{II. .Interview}

For those conditions where the required information is not available written form or not directly measured (difficult to measure) making an interview is one part of data collection method.

\subsubsection{Secondary data}

Other sources are also used as complementary data source agents. Among these sources' internet and reference books, different literature survey and documents of the company were used.

\section{Result and discussion}

\subsection{Existing system}

\subsubsection{Use of hot gases in existing system}

In Messebo Building Materials Production Plc the exhausted gases from Rotary kilns, pre-heater and Calciners are used to heat the incoming feed material and gases then exhausted to the atmosphere. The exhaust gas temperature is averagely around $325^{\circ} \mathrm{C}$.Part of this gas is used in raw mills \& coal mills for drying purpose. The solid material (i.e. Clinker) coming out of the Rotary kiln is at around $1300-1650{ }^{\circ} \mathrm{C}$ and is cooled to $100-120{ }^{\circ} \mathrm{C}$ using ambient air. This generates hot air of about $280-300^{\circ} \mathrm{C}$ which simply is exhausted to the atmosphere. 


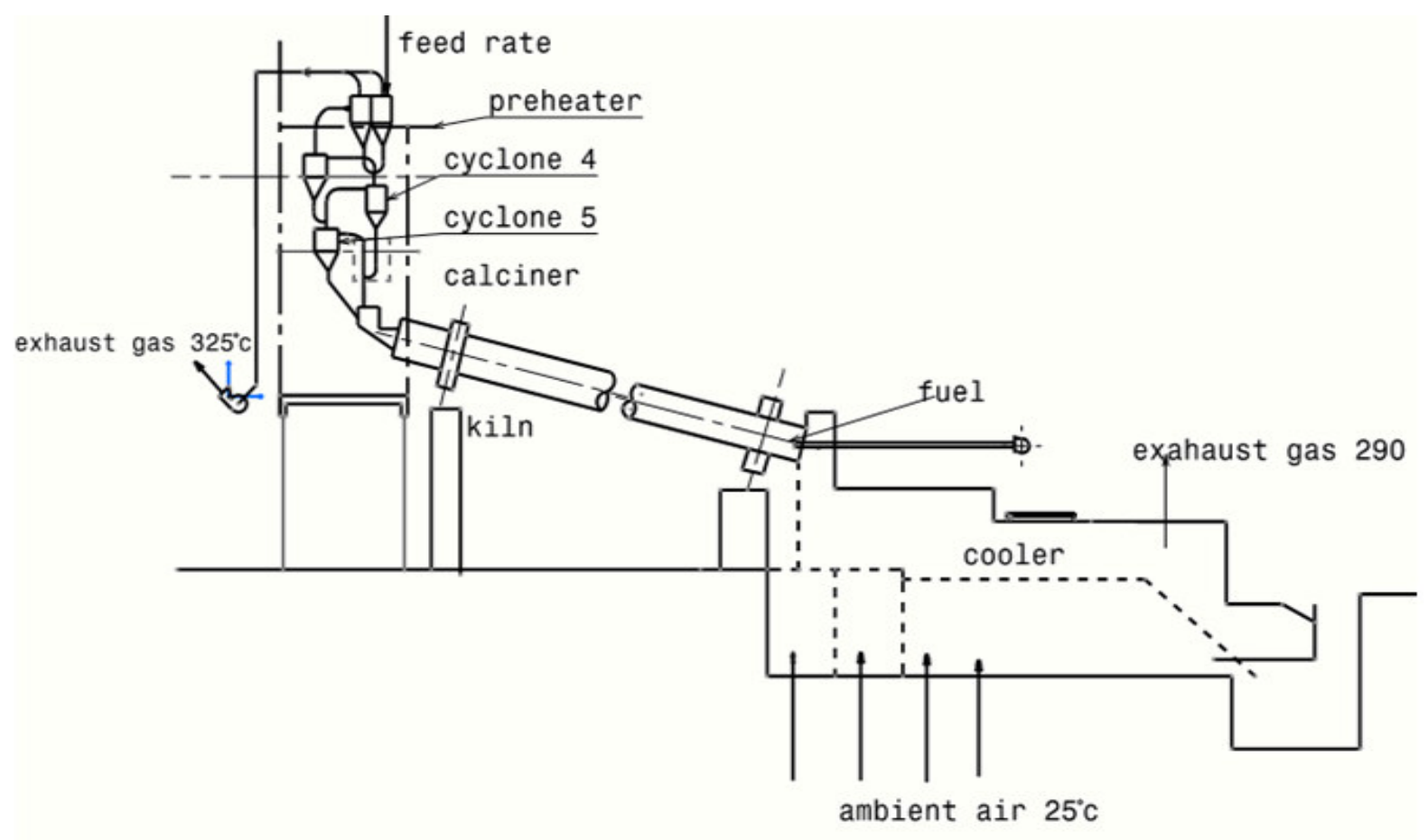

Boundary of pyro processing system in mesebo cement factory

Figure 5: existing system of pyro processing drawing on Catia software

\subsubsection{Numerical calculation and thermodynamic analysis}

In this portion we are calculating the amount of energy (heat) lost from $1 \mathrm{~kg}$ of clinker the system and heat inputs to system required to $1 \mathrm{~kg}$ of clinker .Besides the above figure 5 information we are also consider different data's on each stage of calculation which recorded from CCR and we have used different thermo dynamics laws and principles to analyze the collected data such as Ideal gas laws, first law of thermodynamics thus we take the following thermodynamic assumptions .

* Our reference is $1 \mathrm{~kg}$

* Steady state working conditions.

* The change in the ambient temperature is neglected.

* Cold air leakage (false air) into the system is negligible i.e. no false air enters to the system and exit from the system

* Consider the mass flow rate of air through tertiary air duct is negligible

* the system is control volume or open system

* The coal used is south Africa coal which has calorific value(heating value) of $4000-6500 \mathrm{kcal} / \mathrm{kg}$

Table 1: some calculated and given value

\begin{tabular}{|l|l|l|}
\hline parameter & Value & Unit \\
\hline Kiln output rate clinker & 101.9 & Tone per hour \\
\hline Clinker temperature & 120 & Degree Clausius \\
\hline Kiln feed temperature & 80 & Degree Clausius \\
\hline Ambient temperature & 25 & Degree Clausius \\
\hline Reference temperature & 20 & Degree Clausius \\
\hline Atmospheric pressure & 101.325 & Kilo pascal \\
\hline Moisture in fine coal & 0.5 & Percent \\
\hline Moister in kiln feed & 0.5 & Percent \\
\hline Kiln feed rate (mkf) & 130.97 & Tone per hour \\
\hline Mass of coal to feed calciner (mcc) & 34000 & Kg \\
\hline Mass of coal feed to kiln (mck) & 8000 & Kg \\
\hline
\end{tabular}

So based on above assumptions and given data's(Table 1 and figure 5) lets calculate the following heat loss or the output heat 


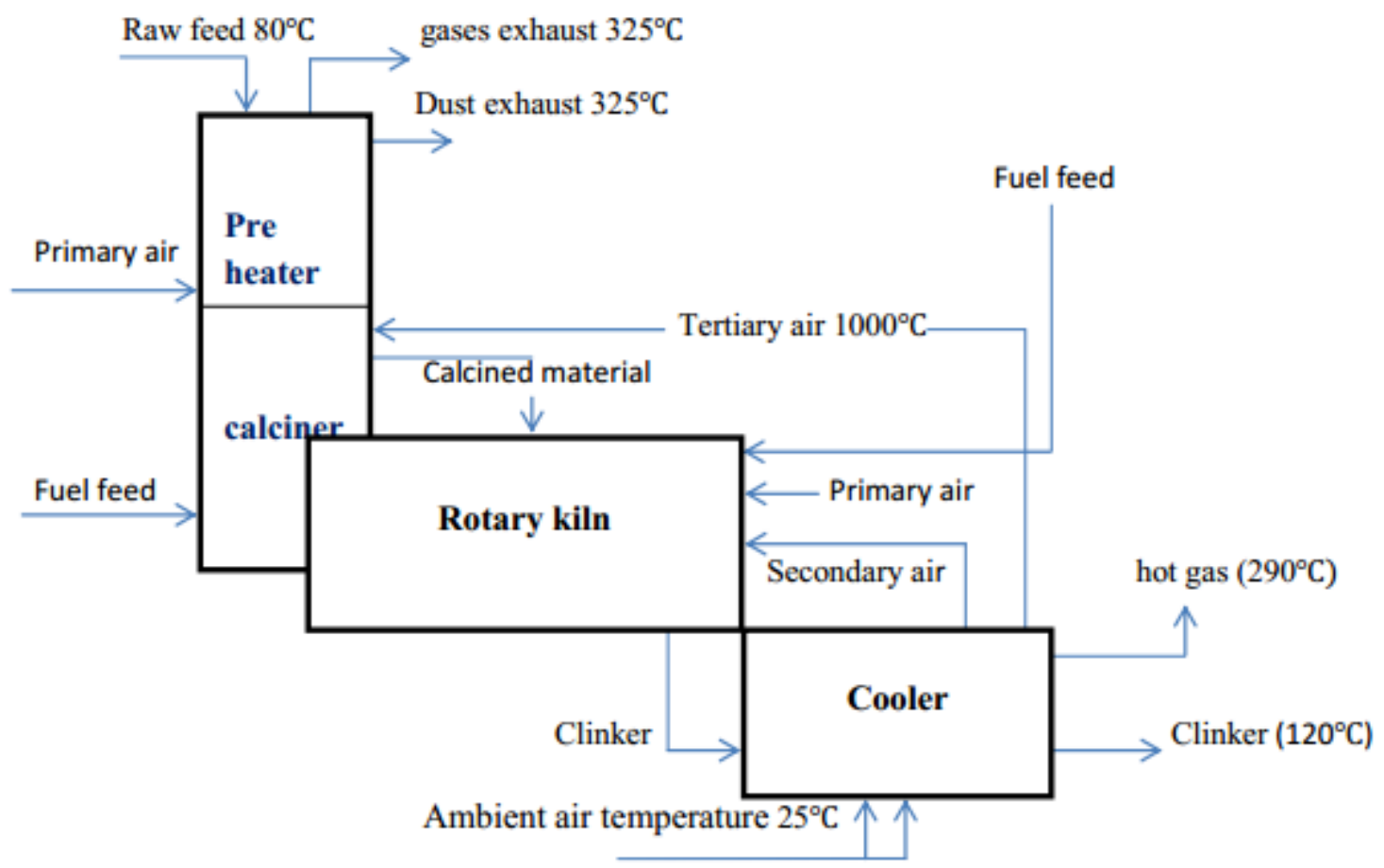

Figure 6: control volume of pyro processing system

The general formula for heat output is given in equation (1) above is .

1. Sensible heat in kiln feed $(\mathrm{Q} 1)=\mathrm{C}_{\mathrm{kf}} \cdot \mathrm{m}_{\mathrm{kf}} . \Delta \mathrm{T}$

Where $\quad \mathrm{mkf}=$ mass of kiln feed, $\mathrm{Ckf}=$ specific heat of kiln feed

With kiln feed of typical lime saturation and calcium carbonate content the kiln feed to clinker factor would be expected to be around 1.54 due to loss of $\mathrm{CO} 2$ from the $\mathrm{CaCO} 3$. That factor is increased by the dust losses from the preheater to the raw mill and dust filters. If the factor is 1.75 then you must have high dust losses from the preheater so improving collection efficiency will reduce the factor. The true raw meal to clinker factor is given by: $1 /(1-$ Loss on ignition of kiln feed $)$ the given percentage loose of material chemical lab. There is $34 \%-36 \%$ lost.

2. Sensible heat due to cooling air $(\mathbf{Q} 2)=m_{c o} C p_{a i r}\left(T_{a}-T_{r}\right)$.

Where $\mathrm{m}_{\mathrm{co}}=$ mass of cooling air, $\mathrm{kg} / \mathrm{kg}$ clinker

\subsubsection{Cooling air fans Cooler fans:}

Instead of cooling the air itself, fans circulate air inside an ambient space. Circulation of air speeds up the evaporation of sweat on our body, hence giving a cool feeling. So, where a fan is only circulating the air, an air cooler is actually providing cool air for relief from hot weather

As stated in [10] Heat Capacities of different Gas mixtures $(\mathrm{Cp})$ is the average of the heat capacities of the components: given by the equation below

$\mathrm{C}^{\mathrm{ig}} \mathrm{P}_{\text {mixture }}=\mathrm{Y}_{\mathrm{A}} \mathrm{C}^{\mathrm{ig}} \mathrm{P}_{\mathrm{A}}+\mathrm{Y}_{\mathrm{B}} \mathrm{C}^{\mathrm{ig}} \mathrm{P}_{\mathrm{B}}+\mathrm{Y}_{\mathrm{C}} \mathrm{C}^{\mathrm{ig}} \mathrm{P}_{\mathrm{C}}+\mathrm{Y}_{\mathrm{D}} \mathrm{C}^{\mathrm{ig}} \mathrm{P}_{\mathrm{D}}$

Where, $\mathrm{y}$ is mole fraction or molar fraction (yi) is defined as the amount of a constituent (expressed in moles), $\mathrm{ni}$, divided by the total amount of all constituents in a mixture (also expressed in moles), $\mathrm{n}_{\text {tot }}[11]$

$\mathrm{Yi}=\sum_{\mathrm{i}=1}^{\mathrm{N}} \mathrm{ni}=\operatorname{ntot} ; \sum_{\mathrm{i}=1}^{\mathrm{N}} \mathrm{Yi}$

Therefore Cmixture $=\left(\mathrm{m} 1 / \mathrm{m}_{\text {mixture }}\right) \mathrm{Cp} 1+\left(\mathrm{m} 2 / \mathrm{m}_{\text {ixture }}\right) \mathrm{Cp} 2+(\mathrm{m} 3 / \mathrm{m} /$ mixture $) \mathrm{Cp} 3$

So let us calculate and Lets assume the gases will be modeled as ideal gases with constant specific heats.

The molar masses of N2, O2, H2O, and CO2are 28.0, 32.0, 18.0, and $44.0 \mathrm{~kg} / \mathrm{kmol}$ respectively

The constant-pressure specific heats of these gases at room temperature are $1.039,0.918,1.8723$, and 0.846 $\mathrm{kJ} / \mathrm{kg} . \mathrm{K}$, respectively. The air properties at room temperature are $\mathrm{cp}=1.005 \mathrm{~kJ} / \mathrm{kg} . \mathrm{K}$, $\mathrm{cv}=0.718 \mathrm{~kJ} / \mathrm{kg} . \mathrm{K}$, and $\mathrm{k}=1.4$ which is the ratio of $\mathrm{Cp}$ and $\mathrm{Cv}$

1. Sensible heat in kiln feed( Q1):

$\mathrm{Q}_{1}=\mathrm{m}_{\mathrm{kf}} \times \mathrm{C}_{\mathrm{Pkf}} \times\left(\mathrm{T}_{\mathrm{kf}}-\mathrm{T}_{\mathrm{r}}\right)^{\circ} \mathrm{C}$

$\mathrm{m}_{\mathrm{kf}}=$ Kiln feed rate/ Kiln output rate clinker

With kiln feed of typical lime saturation and calcium carbonate content the kiln feed to clinker factor would be expected to be around 1.54 due to loss of $\mathrm{CO} 2$ from the $\mathrm{CaCO} 3$. That factor is increased by the dust losses from the preheater to the raw mill and dust filters. If the factor is 1.75 then you must have high dust losses from the preheater so improving collection efficiency will reduce the factor. The true raw meal to clinker factor is given by: 
$1 /(1-$ Loss on ignition of kiln feed $)$ the given percentage loose of material chemical lab. There is $34 \%-36 \%$ lost. $\frac{\text { Raw material feed to kiln }}{\text { clinker production }}=\frac{100}{100-\text { lost }}$, but take the average lost is $=35 \%$

$\frac{100}{100-35}=\frac{100}{65}=1.5384$. But the raw material feed to kiln is $130.97 \frac{\text { ton }}{\text { hour }}$. Then the amount of clinker production from $130.97 \frac{\text { ton }}{\text { hour }}$ raw materials is given by $\frac{130.97 \frac{\text { ton }}{\text { hour }}}{\text { clinker production }}=1.5384$, then

Clinker production $=\frac{1309.7 \frac{\text { ton }}{\text { hour }}}{1.5384}=85.13 \frac{\text { ton }}{\text { hour }}$. But the total clinker out let from the burner includes

Ash from coal. But the percentage of Ash is $2.43 \%-3.01 \%$ of the total coal feed see the table 2 below .

Table 2:percentage of coal constituents in Messebo cement factory

\begin{tabular}{|l|l|}
\hline Elements found in coal & Percentage \% \\
\hline $\mathbf{C}$ & $72-73$ \\
\hline $\mathbf{H}$ & $3-3.5$ \\
\hline $\mathbf{O}$ & $5.5-6$ \\
\hline $\mathbf{N}$ & $1.5-1.75$ \\
\hline $\mathbf{S}$ & $1.5-1.59$ \\
\hline Ash & $2.43-3$ \\
\hline Moisture & $0.25-0.3$ \\
\hline Volatile & $3.77-4.67$ \\
\hline Fixed carbon & $3.77-4.67$ \\
\hline
\end{tabular}

Material feed to kiln $\left(\mathrm{m}_{\mathrm{kf}}\right)=130.97 \frac{\mathrm{kg}}{\mathrm{hour}} \quad$, Mass of coal to feed calciner $\left(\mathrm{m}_{\mathrm{cc}}\right)=34 \frac{\mathrm{kg}}{\text { hour }}$

Mass of coal feed to kiln $\left(\mathrm{m}_{\mathrm{ck}}\right)=8 \frac{\mathrm{kg}}{\mathrm{hour}} \quad \mathrm{M}_{\mathrm{k}}=130.97 \frac{\mathrm{kg}}{\mathrm{hour}}$

Total mass of the coals inter in to main burning system $=M_{\mathrm{cc}}+\mathrm{M}_{\mathrm{ck}}=34000 \frac{\mathrm{kg}}{\mathrm{hour}}+8000 \frac{\mathrm{kg}}{\mathrm{hour}}=42000 \frac{\mathrm{kg}}{\mathrm{hour}}$

Then the amount of Ash produced from total coal feed is given by Ash $=\frac{\% \text { Ash }}{100} * 42000 \frac{\mathrm{kg}}{\text { hour }}$ let take us $3 \%$ from the interval of the above.

Ash $=\frac{3}{100} * 42000 \frac{\mathrm{kg}}{\mathrm{hour}}=1260 \frac{\mathrm{kg}}{\mathrm{hour}}$.

Then the total clinker production $=$ clinker production from raw material + Ash $=85.13 \frac{\mathrm{ton}}{\mathrm{hour}}+21 \frac{\mathrm{kg}}{\mathrm{min}}$

Total clinker production $=1418.83 \frac{\mathrm{kg}}{\mathrm{min}}+1260 \frac{\mathrm{kg}}{\mathrm{hour}}=1439.83 \frac{\mathrm{kg}}{\mathrm{min}}$.

Then the above equation be comes

$\mathrm{Q} 1=1.5384 \times \mathrm{C}_{\mathrm{Pc}} \frac{\mathrm{cal}}{\mathrm{kg}^{\circ} \mathrm{C}} \times(80-20){ }^{\circ} \mathrm{C} \quad \mathrm{CPc}=1.09-1.55 \mathrm{~J} / \mathrm{gk}\left(0.937073-1.24 \mathrm{cal} / \mathrm{kg}^{\circ} \mathrm{C}\right)$

For this calculation take $1.24 \mathrm{cal} / \mathrm{kg} \mathrm{k}$ Therefor Q1 $=114.45 \mathrm{kcal} / \mathrm{kg}$ clinker

2. Sensible heat due to cooling air (Q2)

$\mathrm{Q} 2=\mathrm{m}_{\mathrm{co}} \times \mathrm{C}_{\text {Pair }} \times\left(\mathrm{T}_{\mathrm{a}}-\mathrm{T}_{\mathrm{r}}\right)$

Where, $\mathrm{m}_{\mathrm{co}}=$ mass of cooling air, $\mathrm{kg} / \mathrm{kg}$ clinker

\subsubsection{Cooling air fans Cooler fans}

Cooling air fans are centrifugal fans used to cool the clinker by sucking atmospheric fresh air before crushed by the clinker crusher. As the atmospheric air is meet with the clinker heat exchange takes places. Then the atmospheric air becomes hot air. Part of this hot gas is suck to the kiln burner by the ID fan. But they remain is goes through the cooler Chimney by pulling of EP fan. See the below data that the system has nine fans and data was recorded from CCR computers of the cooler funs volume flow rate and pressure when the system runs.

Table 3: volume flow rat of cooler fans

\begin{tabular}{|l|l|l|}
\hline Fan & Volume flow rate $\left(\mathbf{m}^{\mathbf{3}} / \mathrm{min}\right)$ & Suction pressure $(\mathrm{mbar})$ \\
\hline 1 & 74 & 52 \\
\hline 2 & 74 & 48 \\
\hline 3 & 91 & 45.5 \\
\hline 4 & 639 & 60.8 \\
\hline 5 & 146 & 62.2 \\
\hline 6 & 221 & 45.4 \\
\hline 7 & 208 & 69.1 \\
\hline 8 & 237 & 57.6 \\
\hline 9 & 259.8 & 55.3 \\
\hline total & 1949.8 & 495.9 \\
\hline
\end{tabular}


But mass flow rate of a given system is given by the ration of volumetric flow rate to specific volume. As stated in equation (7) below.

$\mathrm{m}_{\mathrm{co}}=\frac{\sum_{1}^{9} \overline{\mathrm{v}}}{\mathrm{v}}$

but from ideal gas law PV $=\mathrm{nRT}$ where $\mathrm{P}$ is the pressure of the gas, $\mathrm{V}$ is the volume of the gas, $\mathrm{n}$ is the amount of substance of gas (also known as number of moles), $\mathrm{T}$ is the temperature of the gas and $\mathrm{R}$ is the ideal, or universal, gas constant. From this the specific volume of a substance is the ratio of the substance's volume to its mass. It is the reciprocal of density

specific volume $(\mathrm{v})=\mathrm{v} / \mathrm{m}=\mathrm{RT} / \mathrm{p}$

$\mathrm{p} \mathrm{v}=\mathrm{RT}$ thus $\mathrm{v}=\mathrm{RT} / \mathrm{P}$ here $\mathrm{T}=20^{\circ} \mathrm{C}$ which is the reference temperature and the universal gas constant $(\mathrm{R})=$ 287 N.m/kg.k

$P$ is the average of the 9 cooler funs: $\mathrm{p}=495.9 / 9=55.1 \mathrm{mbar}=5510 \mathrm{pa}=5510 \mathrm{~N} / \mathrm{m}^{2}$

So $\mathrm{v}=\mathrm{RT} / \mathrm{P}=\frac{287 \mathrm{~N} \cdot \mathrm{m} / \mathrm{kg} \cdot \mathrm{k} \times 293 \mathrm{k}}{5510 \mathrm{~N} / \mathrm{m} 2}=15.26 \mathrm{~m}^{3} / \mathrm{kg}$

$\mathrm{m}_{\mathrm{co}}=\frac{\sum_{1}^{9} \overline{\mathrm{u}}}{\mathrm{v}}=1949.8 \mathrm{~m}^{3} / \mathrm{min} / 15.26 \mathrm{~m}^{3} / \mathrm{kg}=127.77 \mathrm{~kg} / \mathrm{min}$

So $\mathrm{Q} 2=\mathrm{m}_{\mathrm{co}} \times \mathrm{CP}_{\mathrm{air}} \times\left(\mathrm{T}_{\mathrm{a}}-\mathrm{T}_{\mathrm{r}}\right)=127.77 \mathrm{~kg} / \mathrm{min} \times \frac{1.005 \mathrm{kcal}}{\mathrm{kg}^{\circ} \mathrm{C}}(\times 25-20)^{\circ} \mathrm{C}=642 \mathrm{kcal} / \mathrm{min}$ of clinker

3. Sensible heat in primary air (Q3): this includes both mass of primary air to kiln and mass of primary air to calciner. To calculate the mass of this air the primary fun flow rate and suction pressure is important.

Primary air fans: Primary air fans are a fan that are used to suck fresh air for starting calcinations by calciner side and for starting burning by the main kiln side as the coal is feed from coal mill by the help of blower to both sides. See the table below

Table 4: primary air fans

\begin{tabular}{|c|c|c|c|c|}
\hline Fan & $\begin{array}{c}\text { Direction that fan in } \\
\text { side }\end{array}$ & $\begin{array}{c}\text { Suction } \\
\text { pressure(mbar) }\end{array}$ & $\begin{array}{c}\text { Suction } \\
\text { capacity(m } \mathbf{3} \text { (min) }\end{array}$ & $\begin{array}{c}\text { Atmospheric } \\
\text { temperature }\left(\mathbf{T}_{\mathbf{p}}\right)\end{array}$ \\
\hline $\mathbf{1}$ & Calciner & 19 & 67.36 & 25 \\
\hline $\mathbf{2}$ & Kiln & 20.8 & 73.75 & 25 \\
\hline
\end{tabular}

- So mass of primary air to Calciner $=$ volume of flow rate of primary air funs to calciner divided by specific volume of air and

- mass of primary air to kiln = volume flow rate of the fun that sucks the kiln air divide by specific volume of the air

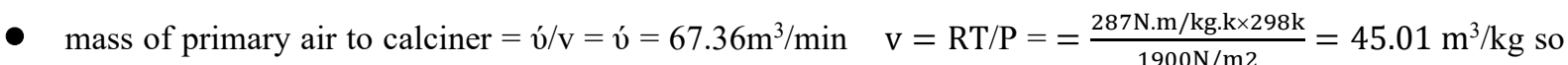
mass of primary air to calciner $=\frac{67.36 \mathrm{~m} 3 / \mathrm{min}}{45.01 \mathrm{~m} 3 / \mathrm{kg}}=$ mass of primary air to calciner $=1.49 \mathrm{~kg} / \mathrm{min}$

- mass of primary air to kiln=v́/v: $\quad \dot{v}=73.75 \mathrm{~m}^{3} / \mathrm{min}, \mathrm{v}=\mathrm{RT} / \mathrm{P}=\frac{287 \mathrm{~N} \cdot \mathrm{m} / \mathrm{kg} \cdot \mathrm{k} \times 298 \mathrm{k}}{2080 \mathrm{~N} / \mathrm{m} 2}=41.12 \mathrm{~m}^{3} / \mathrm{kg}$

- mass of primary air to kiln $=v / \mathrm{v}=\frac{73.75 \mathrm{~m} 3 / \mathrm{min}}{41.12 \mathrm{~m} 3 / \mathrm{kg}}=1.79 \mathrm{~kg} / \mathrm{min}$

So $\mathrm{Q} 3=\mathrm{m}_{\mathrm{p}} \times \mathrm{CP}_{\text {air }} \times\left(\mathrm{T}_{\mathrm{p}}-\mathrm{T}_{\mathrm{r}}\right)$ but $\mathrm{m}_{\mathrm{p}}=$ mass of primary air to kiln + mass of primary air to calciner; $\mathrm{m}_{\mathrm{p}}=$ $1.79 \mathrm{~kg} / \mathrm{min}+1.49 \mathrm{~kg} / \mathrm{min}=3.28 \mathrm{~kg} / \mathrm{min} \quad \mathrm{Cp}_{\text {air }}=1.005 \frac{\mathrm{cal}}{\mathrm{Kg} \mathrm{K}}$

Then $\mathrm{Q} 3=\mathrm{m}_{\mathrm{p}} \times \mathrm{CP}_{\mathrm{air}} \times\left(\mathrm{T}_{\mathrm{p}}-\mathrm{T}_{\mathrm{r}}\right)=3.28 \mathrm{~kg} / \mathrm{min} \times 1.005 \frac{\mathrm{KJ}}{\mathrm{Kg} \mathrm{K}}(25-20)^{\circ} \mathrm{C}$

Q3 $=16.4 \mathrm{kcal} /$ min of clinker

4. Sensible heat of fuel(Q4): before directly goes to calculation see the following necessary date's or points

- The coal temperature is increasing from atmospheric temperature to $75^{\circ} \mathrm{C}$ during drying by absorbing heat from hot gas

- The temperature of the hot gas used for coal mill is maximum-minimum $\left(220-210^{\circ} \mathrm{C}\right)$ and the outlet after drying is $\operatorname{from}(90-80)^{\circ} \mathrm{C}$

The temperature of the hot gas used for raw mill is the same as the temperature outlet from pre heater (mostly $325^{\circ} \mathrm{C}$ ) and the out let after drying the raw material is mostly $110^{\circ} \mathrm{C}$.Having these points in mind let us calculate Q4

$$
\mathrm{Q} 4=\mathrm{m}_{\text {fuel }} \times \mathrm{C}_{\text {Pfuel }} \times\left(\mathrm{T}_{\text {fuel }}-\mathrm{T}_{\mathrm{r}}\right)=\mathrm{m}_{\text {fuel }} \times \frac{1.24 \mathrm{kcal}}{\mathrm{kg}^{\circ} \mathrm{C}} \times(75-25)^{\circ} \mathrm{C} \text { here the mass of fuel is not known. We }
$$

can get as follow

$1 \mathrm{~kg}$ clinker $=780 \mathrm{k} \mathrm{cal}$

$1 \mathrm{~kg}$ of South Africa coal $=6500 \mathrm{kcal}$ 


$$
? \text { y kg SA } \quad=780 \mathrm{kcal}
$$

$1 \mathrm{kgSA} \times 780 \mathrm{kcal}=\mathrm{y} \mathrm{kg} \mathrm{SA} \times 6500 \mathrm{kcal} / \mathrm{kg}$ of clinker

$\mathrm{y}=0.12 \mathrm{~kg}$ which is $\mathrm{m}_{\text {fuel }}$

$\therefore \mathrm{Q} 4=0.12 \mathrm{~kg} \times \frac{1.24 \mathrm{kcal}}{\mathrm{kg}^{\circ} \mathrm{C}} \times(75-25)^{\circ} \mathrm{C}$

$\mathrm{Q} 4=7.44 \mathrm{kcal} / \mathrm{kg}$ of clinker

\section{Heat from combustion of $\operatorname{coal}\left(Q_{5}\right)$ :}

$\mathrm{Q} 5=\mathrm{m}_{\text {fue }} \times$ calorfic value of the South Africa coal

$\mathrm{Q} 5=0.12 \mathrm{~kg} \times 6500 \mathrm{kcal} / \mathrm{kg}$ of clinker $=780 \mathrm{kcal} / \mathrm{kg}$ of clinker

\subsubsection{Heat out put}

6. Heat formation clinker $\left(\Delta \mathbf{H}_{\mathbf{R}}\right)$ : Heat of formation of clinker: This is the heat to convert the raw material to clinker. This is termed the theoretical heat of formation of the raw meal, from first principles by using heat of reaction data. A more rapid estimation of this heat can be done by using a formula developed by ZurStrassen (1957) which gives good agreement with basic calculations. This formula is: $\mathrm{Qth}=2.22 \mathrm{~A}+7.64 \mathrm{C}-5.116 \mathrm{~S}$ $-0.59 \mathrm{~F}$

Where Qth = theoretical heat of the formation

$\mathrm{A}, \mathrm{M}, \mathrm{C}, \mathrm{S}$ and $\mathrm{F}$ are the percentage of $\mathrm{AW} 3, \mathrm{MgO}, \mathrm{CaO}, \mathrm{SiO} 2$ and $\mathrm{Fe} 2 \mathrm{Os}$ in the clinker

$\left(\Delta \mathrm{H}_{\mathrm{R}}\right):=2.22 \mathrm{Al} 2 \mathrm{O} 3+6.4 \mathrm{MgO}+7.646 \mathrm{CaO}-5.116 \mathrm{SiO} 2-0.59 \mathrm{Fe} 2 \mathrm{O} 3$

$$
\begin{aligned}
& =2.22(13.5)+6.4(0.0004)+7.646(79.9)-5.116(5.4)-0.59(1.5) \\
& =612.408 \mathrm{kcal} / \mathrm{kg} \text { clinker }
\end{aligned}
$$

\section{Heat in preheater exit $\operatorname{dust}(Q 6)$}

$$
\mathrm{Q} 6=\mathrm{m}_{\mathrm{d}} \times \mathrm{CP}_{\mathrm{d}} \times(\mathrm{Te}-\mathrm{Tr})
$$

Where $m_{d}=$ mass of dust

From table the company uses averagely $130.976 \mathrm{t} / \mathrm{h}$ from this $90 \%$ of this fed is going to the system the rest is returned as a dust through preheater to the atmosphere. That means from the total $130.976 \mathrm{TPH}$ i.e. 130.976 $\times \frac{90}{100}=117.84 \mathrm{TPH}$ is go to the system and $13.097 \mathrm{TPH}$ is return as a dust. $13.097 \mathrm{TPH}=218 \mathrm{~kg} / \mathrm{min}$ is its mass flow rate.

Then mass of dust $=$ kiln feed to clinker factor $\times$ preheater return dust $\%$

$$
\mathrm{m}_{\mathrm{d}}=1.5384 \times 0.01=0.015384
$$

$\mathrm{Q} 6=0.015384 \times 0.23 \mathrm{kcal} / \mathrm{kg}^{\circ} \mathrm{C} \times(325-20)^{\circ} \mathrm{C}$

$\mathrm{Q} 6=1.079 .7 \mathrm{kcal} / \mathrm{min}$ of clinker

\section{Heat in preheater exit gases (Q7):}

$\mathrm{Q} 7=\mathrm{m}_{\mathrm{e}} \times \mathrm{CP}_{\mathrm{e}} \times(\mathrm{Te}-\mathrm{Tr})$

The exhaust gases through the preheater cyclone are $\mathrm{O} 2, \mathrm{CO}$ and $\mathrm{NOx}$ let as calculate their density on their dry bases because the moisture from kiln feed and coal in preheater is very small. Average of O2 is 26.36 and total average of CO is 0.62257 and the amount of NOx is $2000-3000 \mathrm{ppm}$ which is averagely around 0.0025 .so the totally is 26.98

Table 5: pre heater exhaust gases $\%$

\begin{tabular}{|c|l|l|}
\hline Exhaust gas & \multicolumn{1}{|c|}{$\%$} & Molecular Weight \\
\hline O2 & 97.70 & 32 \\
\hline CO & 2.3075 & 28 \\
\hline NOx & 0.0098 & 72 \\
\hline
\end{tabular}

As written in different literatures at standard conditions, $0^{\circ} \mathrm{C}$ and one atmosphere, one kilomole of gas occupies $22.414 \mathrm{~m}^{3}$ and the universal gas constant is $8314.5 \mathrm{~J} /(\mathrm{kmol} . \mathrm{K})$. So the density of the above gases at standard temperature and pressure (stp) is calculated as follow using equations ( 9 and 10).

Mass $=$ number of moles substance $\times$ molecular weight of the substance

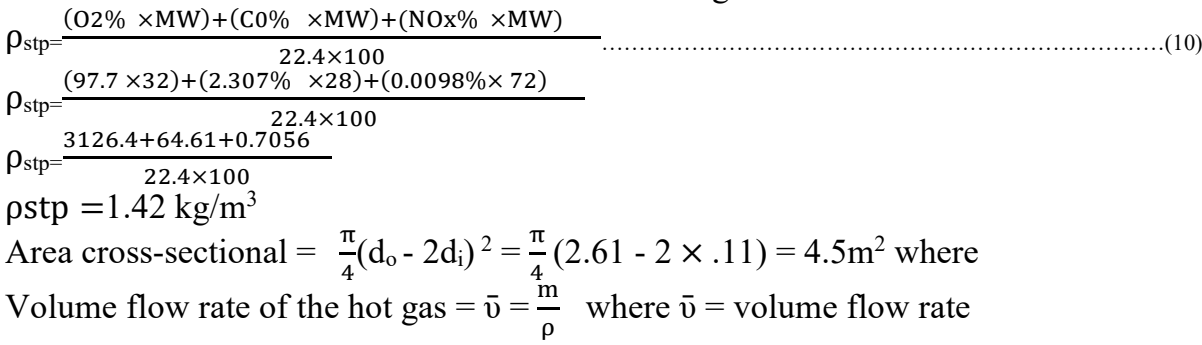

- The temperature of exhaust gas averagely $325.16^{\circ} \mathrm{C}$

- The pressure is vary from 51.68 mbar but we take the most repeated 56mbar.(taken from CCR)

- The volume flow rate of the hot gas and we take from CCR(central control room) is $9500 \mathrm{~m}^{3} / \mathrm{min}$ 
Volume flow rate of the hot gas $=\bar{v}=\frac{\mathrm{m}}{\rho}=$ so the mass flow rate $=\bar{v} \times \rho$

$$
=9500 \mathrm{~m}^{3} / \mathrm{min} \times 1.42 \mathrm{~kg} / \mathrm{m}^{3}=13490 \mathrm{~kg} / \mathrm{min}
$$

$\mathrm{Q} 7=13490 \mathrm{~kg} / \mathrm{min} \times \mathrm{CPof}$ thegases $\times(325.16-20)^{\circ} \mathrm{C}$

But specific heat of mixture is given by $\frac{\sum \text { micpi }}{\sum \mathrm{mi}}$

Where $m_{i}=$ mass of the gases

$\mathrm{CP}_{\mathrm{i}}=$ specific heat of individual gases

Specific heat of mixture is given as follow

$$
=\frac{\sum \mathrm{micpi}}{\sum \mathrm{mi}}=\frac{\left.\left.\left.\sum(28 \mathrm{~kg} / \mathrm{mol} \times 1.02 \mathrm{~kJ} / \mathrm{kg} \mathrm{K})+32 \mathrm{~kg} / \mathrm{mol} \times 0.919 \mathrm{~kJ} / \mathrm{kg} \mathrm{K}\right)+28 \mathrm{~kg} / \mathrm{mol} \times 0.995 \mathrm{~kJ} / \mathrm{kg} \mathrm{K}\right)\right)+46 \mathrm{~kg} / \mathrm{mol} \times 1.013 \mathrm{kj} / \mathrm{kgk}}{\sum 134 \mathrm{~kg} / \mathrm{mol}}
$$

So specific het of the gases $=0.9817 \mathrm{~kJ} / \mathrm{kg} \mathrm{K}$

Then heat in pre heater exit gases (Q7) is calculated as follow

$\mathrm{Q} 7=13490 \mathrm{~kg} / \mathrm{min} \times 0.9817 \mathrm{~kJ} / \mathrm{kg} \mathrm{K} \times(325.16-20)^{\circ} \mathrm{C}$

$\mathrm{Q} 7=4041274 \mathrm{kj}^{\circ} \mathrm{C} / \mathrm{kmin}=1103267802 \mathrm{kj} / \mathrm{min}$

$\mathrm{Q} 7=18387796.8 \mathrm{kj} / \mathrm{sec}$

9. Heat in clinker from cooler discharge $(\mathrm{Q} 8)$ :

$\mathrm{Q} 8=\mathrm{m}_{\mathrm{c}} \times \mathrm{CP}_{\mathrm{c}} \times(\mathrm{Tc}-\mathrm{Tr})$

$\mathrm{Q} 8=1 \times 0.193 \mathrm{kcal} / \mathrm{kg}^{\circ} \mathrm{C} \times\left(120^{\circ} \mathrm{C}-20^{\circ} \mathrm{C}\right)$

$\mathrm{Q} 8=19.3 \mathrm{kcal} / \mathrm{kg}$ clinker

10. Heat in cooler exhaust air (Q9):

$\mathrm{Q} 9=\mathrm{m}_{\mathrm{ce}} \times \mathrm{CP}_{\mathrm{ce}} \times($ Tce $-\mathrm{Tr})$

the clinker grate cooler produces $1-2 \mathrm{~kg} / \mathrm{h}$ of exhaust air per kilogram of clinker. Under normal operating conditions, this exhaust air has a temperature of approximately $280-300^{\circ} \mathrm{C}$, which can temporarily increase to $350^{\circ} \mathrm{C}$ or decrease to $\leq 230^{\circ} \mathrm{C}$ under abnormal operation(condition).

$\mathrm{Q} 9=1.5 \mathrm{~kg} / \mathrm{h} \times 0.25 \mathrm{kcal} . \mathrm{kg}-1 .{ }^{\circ} \mathrm{C}-1 \times(290-20){ }^{\circ} \mathrm{C}$

$$
\text { Air: } \mathrm{CP}_{\mathrm{ce}}=1.005 \frac{\mathrm{KJ}}{\mathrm{Kg} \mathrm{K}}
$$

$$
\mathrm{Q} 9=1.6875 \mathrm{kcal} / \mathrm{min} \text { of clinker }
$$

\section{Heat loss due to the radiation from the preheater cyclones and kiln surface:}

Radiation loss $=\sigma \times\left(\mathrm{Ts}^{4}-\mathrm{Tr}^{4}\right) \times$ surface area

$\checkmark \quad$ Radiation loss from pre heater cyclones surface considered as cylindrical in geometry. So formula for finding

\begin{tabular}{|c|c|c|c|c|c|}
\hline Cyclones & Length (m) & Diameter(m) & $\begin{array}{c}\text { Surface area } \\
2 \pi r^{2}+2 \pi r h\end{array}$ & $\operatorname{Max} \operatorname{temp}\left({ }^{\circ} \mathrm{C}\right)$ & Min temp $\left({ }^{\circ} \mathrm{C}\right)$ \\
\hline Cyclone4 & 18 & 5.7 & 373.17 & 196 & 132 \\
\hline Cyclone5 & 18 & 5.7 & 373.17 & 291 & 155 \\
\hline
\end{tabular}
the surface area of a cylinder is, with $h$ as height, $r$ as radius, and $S$ as surface area is $S=2(\pi) r h+2(\pi) r$

That is Surface area $=2 \pi r^{2}+2 \pi r h$

Table 6: area and surface temperature of cyclone 4 and 5

Radiation loss from pre heater cyclone $(\mathrm{Qc} 1)=\sigma \times\left(\mathrm{T}_{\max }{ }^{4}-\mathrm{T}_{\min }{ }^{4}\right) \times$ surface area.

Where $\sigma=4.88 \times 10^{-8} \mathrm{kcal} / \mathrm{m}^{2}-\mathrm{k}^{4}$

$\checkmark \quad \mathrm{Qc} 4=4.88 \times 10^{-8} \mathrm{kcal} / \mathrm{m}^{2}-\mathrm{k}^{4}\left(196^{4}-132^{4}\right) 373.17 \mathrm{~m}^{2}$

$\mathrm{Qc} 4=20256.95 \mathrm{kcal}$

$\checkmark \quad \mathrm{Qc5}=4.88 \times 10^{-8} \mathrm{kcal} / \mathrm{m}^{2}-\mathrm{k}^{4}\left(291^{4}-155^{4}\right) 373.17 \mathrm{~m}^{2}$

Qc5 $=120020 \mathrm{kcal}$

So the total Radiation loss from pre heater cyclones surface $=$ Qc4 + Qc5 $=140276.95 \mathrm{kcal}=587.199 \mathrm{~kJ}$

$\checkmark$ Radiation loss from kiln system: the kiln found in the company is $57 \mathrm{~m}$ in length and $3.7 \mathrm{~m}$ in diameter and is divided in to 3 main zones. Kiln is cylindrical in geometry. So formula for finding the surface area of a cylinder is, with $h$ as height, $r$ as radius, and $S$ as surface area is $S=2(\pi) r h+2(\pi) r$

That is Surface area $=2 \pi r^{2}+2 \pi r h$ 


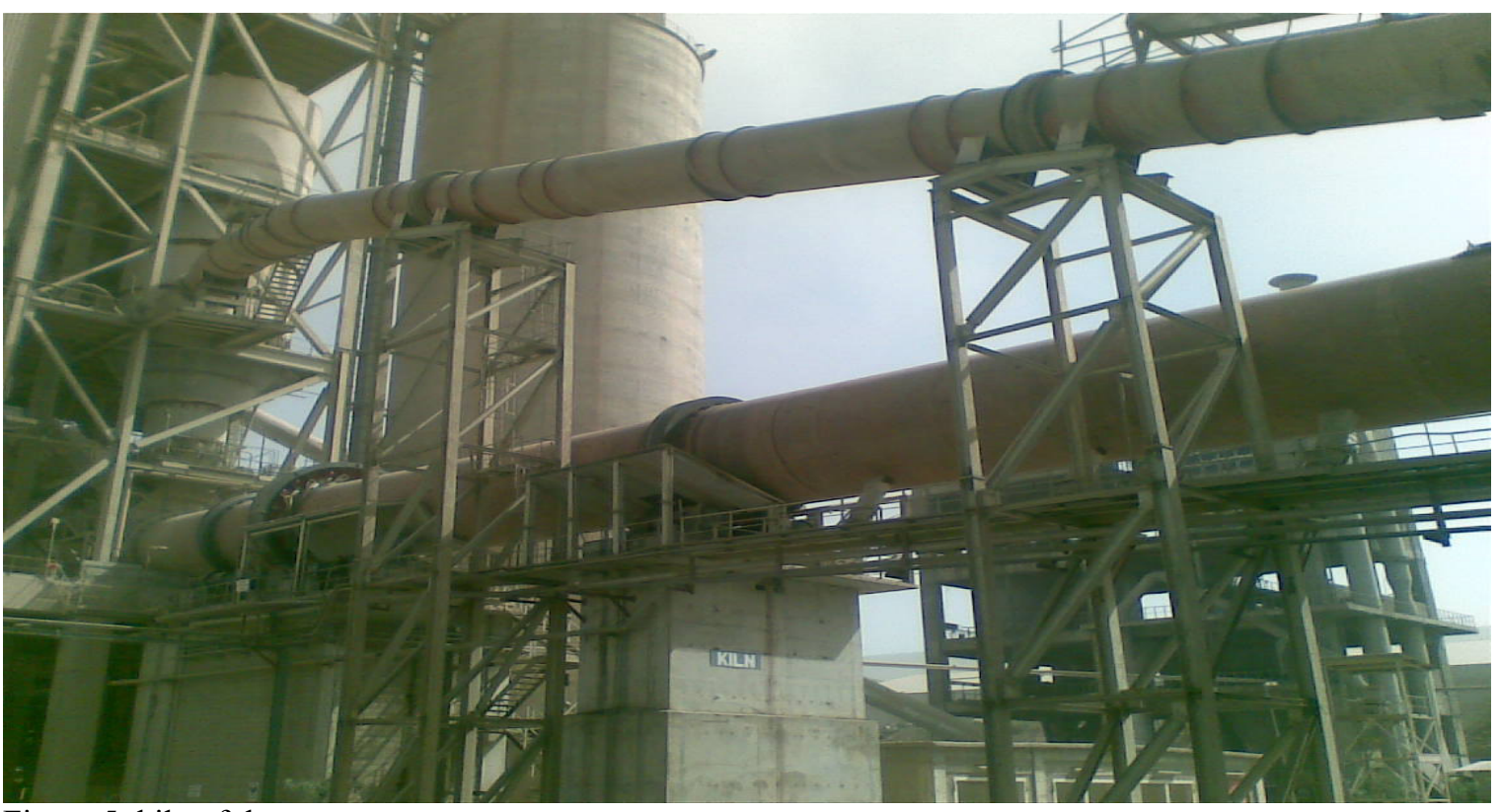

Figure 5: kiln of the company

As shown in the above figure the kin system have cylindrical shape.so we calculating the formula which is used to calculate surface area of cylinder's as shown in the table below

Table 7: kiln surface temperature and surface area

\begin{tabular}{|c|c|c|c|c|c|}
\hline Kiln zone & Length (m) & Diameter(m) & $\begin{array}{l}\text { Surface area }= \\
2 \pi r^{2}+2 \pi r h \text { in } m^{2}\end{array}$ & $\operatorname{Max}$ temp $\left({ }^{\circ} \mathrm{C}\right)$ & Min temp $\left({ }^{\circ} \mathrm{C}\right)$ \\
\hline In let zone & 16.5 & 3.7 & 213.187 & 291 & 149 \\
\hline Transition zone & 33 & 3.7 & 404.88 & 298 & 151 \\
\hline $\begin{array}{l}\text { Higher burning } \\
\text { zone }\end{array}$ & 1.5 & 3.7 & 38.97 & 300 & 161 \\
\hline
\end{tabular}

So the heat loss due to radiation from the kiln surface calculated as follow using equation (10)

Radiation loss $=\sigma \times\left(\mathrm{T}_{\max }{ }^{4}-\mathrm{T}_{\min }{ }^{4}\right) \times$ surface area

$\mathrm{Qi}=\mathrm{Ai} \sum_{\mathrm{j}=1}^{3} \times \sigma\left(\mathrm{Ts}^{4}-\mathrm{Tr}^{4}\right)$

- Radiation Heat loss from inlet zone(Qiz) $=\sigma \times\left(\mathrm{T}_{\max }{ }^{4}-\mathrm{T}_{\min }{ }^{4}\right) \times$ surface area

Where $\sigma=4.88 \times 10^{-8} \mathrm{kcal} / \mathrm{m}^{2}-\mathrm{k}^{4}$

$\mathrm{Qiz}=4.88 \times 10^{-8} \mathrm{kcal} / \mathrm{m}^{2}-\mathrm{k}^{4}\left(291^{4}-149^{4}\right) \times 213.187 \mathrm{~m}^{2}$

$\mathrm{Qiz}=69474.61 \mathrm{kcal}$

- Radiation Heat loss from transition zone(Qtz):

$=4.88 \times 10^{-8} \mathrm{kcal} / \mathrm{m}^{2}-\mathrm{k}^{4}\left(298^{4}-151^{4}\right) 404.88 \mathrm{~m}^{2}=145543.72 \mathrm{kcal}$

Radiation Heat loss from higher burning zone (Qhbz):

$=4.88 \times 10^{-8} \mathrm{kcal} / \mathrm{m}^{2}-\mathrm{k}^{4}\left(300^{4}-161^{4}\right) 38.97 \mathrm{~m}^{2}=14126.28 \mathrm{kcal}$

So the total heat loss from the kiln surface by radiation $=\mathrm{Qiz}+\mathrm{Qtz}+\mathrm{Qhbz}=229143.28 \mathrm{kcal}$

$=959.13 \mathrm{MJ}$

Then total amount of heat output $=\Delta \mathrm{Hr}+\mathrm{Q} 6+\mathrm{Q} 7+\mathrm{Q} 8+\mathrm{Q} 9+$ Radiation loss from cyclone4 and 5+radion loss from kiln surface

There for the total amount of heat output $=612.48 \mathrm{kcal} / \mathrm{clinker}+1.079 \mathrm{kcal} / \mathrm{min}$ clinker $+1103267802 \mathrm{kj} / \mathrm{min}+$ $19.3 \mathrm{kcal} / \mathrm{kgclinker}+1.6875 \mathrm{kcal} / \mathrm{min}$ clinker $+587.199 \mathrm{~kJ}+959.13 \mathrm{~kJ}$

$=2649.267 \mathrm{~kJ}$

Let us calculate the power gained from the heat loss for one month period of time. Power is the rate of using or supplying energy and is given by the following formula:

Power $(p)=\frac{\text { energy }}{\text { time }}$

Where: Power is measured in watts $(\mathrm{W})$

: Energy is measured in joules $(\mathrm{J})$

: Time is measured in minute

N.B $1 \mathrm{kcal}=4186 \mathrm{~J}$

3.1.5 summary of powers which is gained from heat loss and the amount birr saved

$\mathrm{P} 1$ (from exhaust dust $)=\mathrm{Q} 6 / 1 \mathrm{month}(\mathrm{hr})=1.079 \mathrm{kcal} / \mathrm{kg}$ min clinker $/ 43200 \mathrm{~min}=0.1045 \mathrm{w}$

$\mathrm{P} 2($ from pre heater exit gases) $=\mathrm{Q} 7 / 1 \mathrm{month}(\mathrm{min})=1103267802 \mathrm{kj} / \mathrm{min} / 43200 \mathrm{~min}=25538 \mathrm{w}$ 
P3 (from clinker from cooler discharge $(\mathrm{Q} 8)$ ) $=19.3 \mathrm{kcal} / \mathrm{kg}$ clinker $/ 43200=1.87 \mathrm{~W}$

P4 (cooler exhaust air $(\mathrm{Q} 9))=1.6875 \mathrm{kcal} / \mathrm{min}$ clinker $/ 43200=0.163 \mathrm{~W}$

P5 (from cyclone 4 and 5 ) $=587.199 \mathrm{~kJ} / 43200 \mathrm{~min}=13.59 \mathrm{KW}$

P6 $($ from kiln surface $)=959.13 \mathrm{~kJ} / 43200 \mathrm{~min}=22.20 \mathrm{kw}$

But the average unit of price of the electric city is $\mathbf{0}$. 6birr / $\mathbf{k w}$.having this point then let us calculate the Cost saving and Energy saved.

* Energy saved $=$ power gained (generated) $\times$ hours of usage in full capacity per month

* Cost saving $=$ energy saving $\times$ energy cost

Energy saved $($ from $\mathrm{p} 1)=0.1045 \mathrm{w} \times 720 \mathrm{hr}=75.274 \mathrm{whr} / \mathrm{month}=0.07527 \mathrm{kwhr} / \mathrm{month}$

$>$ Cost saving $=0.6 \mathrm{birr} / \mathrm{kw} \times 0.07524 \mathrm{kwhr} / \mathrm{month}=0.045 \mathrm{birr} / \mathrm{month}$

Energy saved $($ from $\mathrm{p} 2)=25538 \mathrm{w} \times 720 \mathrm{hr}=18387360 \mathrm{whr} / \mathrm{month}=18387.734 \mathrm{kwhr} / \mathrm{month}$

$>$ Cost saving $=0.6 \mathrm{birr} / \mathrm{kw} \times 18387.734 \mathrm{kwhr} / \mathrm{month}=11032 \mathrm{birr} / \mathrm{month}$

Energy saved $($ from $\mathrm{p} 3)=1.87 \mathrm{w} \times 720 \mathrm{hr}=1346 \mathrm{whr} / \mathrm{month}=1.34 \mathrm{kwhr} / \mathrm{month}$

$>$ Cost saving $=0.6 \mathrm{birr} / \mathrm{kw} \times 1.34 \mathrm{kwhr} / \mathrm{month}=0.80 \mathrm{birr} / \mathrm{month}$

Energy saved $($ from $\mathrm{p} 4)=0.163 \mathrm{w} \times 720 \mathrm{hr}=117.36 \mathrm{whr} / \mathrm{month}=0.11736 \mathrm{kwhr} / \mathrm{month}$

$>$ Cost saving $=0.6 \mathrm{birr} / \mathrm{kw} \times 0.11736 \mathrm{kwhr} / \mathrm{month}=0.07 \mathrm{birr} / \mathrm{month}$

Energy saved $($ from p5) $=13.59 \mathrm{KW} \times 720 \mathrm{hr}=9784 \mathrm{kwhr} / \mathrm{month}$

$>$ Cost saving $=0.6 \mathrm{birr} / \mathrm{kw} \times 9784 \mathrm{kwhr} / \mathrm{month}=5870 \mathrm{birr} / \mathrm{month}$

Energy saved $($ from p6) $=22.20 \mathrm{KW} \times 720 \mathrm{hr}=15984 \mathrm{kwhr} / \mathrm{month}$

$>$ Cost saving $=0.6 \mathrm{birr} / \mathrm{kw} \times 15984 \mathrm{kwhr} / \mathrm{month}=9590 \mathrm{birr} / \mathrm{month}$

\section{CONCLUSION}

The cement sector is one of the most energy highly uses industries. The clinker Calcination process is the most energy consuming in cement production, because of the exit gases from the clinker cooler and pre-heater and from the kiln surface.

The aim of this study was to determine the amount of heat loss energy and to identify the main source of the heat losses, and to set possible solutions

The amount of heat loss and major heat losses for the system were identified as the preheater exhaust gases and heat carried away by cooler vent air (grate cooler). In addition to this the power generated and cost saved was discussed. See the table below main parts.

Table 8: summarized recoverable heat from selected devices

\begin{tabular}{|l|l|l|l|l|}
\hline $\begin{array}{l}\text { Source of the heat } \\
\text { loss }\end{array}$ & $\begin{array}{l}\text { Amount of heat } \\
\text { loss }\end{array}$ & $\begin{array}{l}\text { 1.60Power } \\
\text { generated(kw) }\end{array}$ & $\begin{array}{l}1.61 \text { Energy saved } \\
\text { (kwhr/month) }\end{array}$ & $\begin{array}{l}1.62 \text { Amount of } \\
1.63 \text { cost } \\
\text { saved(birr/month) }\end{array}$ \\
\hline $\begin{array}{l}\text { Preheater exhaust } \\
\text { gases }\end{array}$ & $\begin{array}{l}1103267802 \\
\mathrm{~J} / \mathrm{min}\end{array}$ & 25.53 & 18387.73 & 11032 \\
\hline Kiln surface & $959.13 \mathrm{~kJ}$ & 22.20 & 15984 & 9590 \\
\hline $\begin{array}{l}\text { Preheater cyclone4 } 4 \\
\text { and 5 }\end{array}$ & $587.199 \mathrm{~kJ}$ & 13.59 & 9784 & 5870 \\
\hline
\end{tabular}

The power generated is used to powered 2480 light bulbs with 25 -watt capacity. Generally important efforts are being made to continue for saving the energy for the cement industry, Successful reduction of fuel consumption contributes to lower fuel cost, higher clinker production, lower electricity consumption by recover the waste heat.

\section{References}

1. M. Sathiyamoorthy, Dr. Mazda Biglari, The Waste Heat Recovery And Utilization For Power Generation In A Cement Plant (Phase-1 Abu Dhabi : nternational Journal of Advanced Research in IT and Engineering, April 2016, Vol. 5. ISSN: 2278-6244.

2. . Jain, Mayank Sohgoura and Dr. RK ,Investigation of waste heat r ecovery in c ement industry. P-ISSN 23498528, s.1. : International Journal of Chemical Studies, 03-10-2016.

3. Carbon Turst . Heat recovery A guide to key systems and applications. UK : s.n., August 2011.

4. Europian Commision, Sustainable Industry Low Carbon scheme 67/G/ENT/CIP/13/D/N03S02. 30/06/2015.

5. B. Abnay, A. Aharoune etal ,Potential of recovery and conversion of waste heat from rejected exhaust gases ,in Moroccan industry: Application to the cement manufacturing sector, Issue 2, s.1. : Journal of Materials and Environmental Sciences, 2017 , Vol. Volume 8. ISSN : 2028-2508.

6. Dr. Martin Pehnt, Jan bödeker etal,industrial waste heat - tapping into a neglected efficiency potential. 2011

7. Cecilia Arzbaecher, Ed Fouche, and Kelly Parmenter etal,. Industrial Waste-Heat Recovery: Benefits and Recent Advancements in Technology and Applications . s.l. : ACEEE Summer Study on Energy Efficiency in Industry, 2007. 
8. Neeharika Naik dhungel, Waste Heat To Power Systems. May 30, 2012

9. CFD Simulation of Flue Gas Ducting In Waste Heat Recovery Plant, International Journal Of Engineering Sciences \& Research Technology October, 2017, issn: 2277-9655

10. Yunus A. Cengel Thermodynamics: An Engineering Approach, Eighth Edition

11. Perry's Chemical Engineers' Handbook Seventh Edition 